COLUMN

\title{
Copyright in the networked world: copies in courses
}

\author{
Michael Seadle
}

\author{
MSU Libraries, Michigan State University, East Lansing, Michigan, USA
}

\begin{abstract}
Purpose - This column looks at questions from teaching faculty about the use of copyright protected materials in an online course.

Design/methodology/approach - Copyright guidelines are considered. The US TEACH Act and Fair Use statutes are examined, as well as how to make a risk assessment for the institution.

Findings - US universities have a reasonable freedom to use protected materials in the virtual equivalent of face-to-face teaching, as long as it costs the rights holders no loss of expected income and as long as it takes into account the litigiousness of certain firms and associations.

Originality/value - Each copyright use assessment has unique circumstances, but a discussion of the reasoning behind an actual case helps to build a community of good practice that strengthens similar assessments.
\end{abstract}

Keywords Copyright law, Risk assessment, Law enforcement

Paper type Case study

\section{Introduction}

Copyright, like many areas of the law, is all about specifics, and this is especially true for the exemptions on "fair use" (17 USC 107, 2006) and teaching (17 USC 110, 2006). It is possible to give instructors some general guidelines that help them to avoid obvious problems, but overly strict guidelines discourage people from taking advantage of legitimate exemptions - which can cost the university and its students money - and overly lax guidelines can lead to lawsuits.

This article has two parts. In the first, I discuss a set of guidelines that I created for copyright workshops that I teach at Michigan State University (MSU). In the second, I look at an actual set of questions from an instructor to show where the guidelines apply, and where a more detailed examination of the specifics becomes necessary.

\section{Guidelines}

At MSU I am the person who holds workshops twice each semester for graduate students, faculty, and staff about the use of copyright-protected materials in teaching and research. Since, I also answers questions from MSU faculty about the use of copyright protected materials in the classroom, I developed the following guidelines to filter out some of the most basic questions for distance education, including hybrid courses that mix internet and classroom instruction:

These are rules-of-thumb for using copyright-protected materials in Internet-based distance education classes where: a) the materials are in available only within a password protected environment with access restricted to enrolled students (e.g. Angel); b) any MSU

Copyright in the networked world

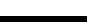


LHT

24,2

\section{6}

recommendations regarding technological protections have been followed; c) the works are available only for limited periods.

- Text. Use small portions of a text-based work, and never more than you would during face-to-face teaching.

- Images. Use images only as you would during face-to-face teaching. When print-based images must be digitized, use low resolution versions that reference the original source. If the image is for sale at a fair price, it should be licensed.

- Multimedia. Use no more than 30 seconds or 10 per cent (whichever is shorter) of a musical work; and use no more than 3 minutes or 10 per cent (whichever is shorter) of an audiovisual work. Never use more than you would during face-to-face teaching.

- Use. Use the materials to support or illustrate a point in an active way, as you would with a peer-reviewed article. Background readings that would normally be purchased in a course pack or text book may not be used. (See the section on "Electronic Reserves.")

- Citation. Include a full citation for the work, as you would do in an academic paper.

- Links. Use links to materials available elsewhere on the Internet, rather than copying the work.

- Technology protections. It is currently illegal to break a technological protection in order to make a copy of a work. - Seadle, 2005

These are not official university guidelines, in part because that could involve liability for the university, but also because making them official would not make them any more useful to instructors and would make them much harder to change as circumstances (and case law) require.

The source of the recommendations about text-based copies come in part from guidelines developed during discussions when Congress was writing the 1976 Copyright Law. These guidelines do not have the force of law, but they do have a thirty-year history of acceptance and the Association of American Publishers sill makes them available on their website (US Copyright Office, 1998; AAP, 1976). Nonetheless the Supreme Court decision in Harper and Row, Publishers, Inc., et al. vs Nation Enterprises et al. (1985) serves as a warning that even a small amount of copying could be problematic, if the section copied represented the "heart of the book."

The source of the recommendations about multimedia copies comes from the "Fair use guidelines for educational multimedia” prepared by a subcommittee of the Judiciary Committee of the USHouse of Representatives (1996). Even though these guidelines have a legislative origin, they never became part of US law and may not stand up in a court case. They provide some protection against a charge of willful infringement, nothing more.

The source of the recommendations about technological protections and citations come from the Digital Millennium Copyright Act (1998). The recommendations about use, images, and links come from a variety of legal cases. As is often the case in copyright law, the penalties are clearer than the exceptions.

In theory an instructor could use these guidelines to include a paragraph from a multi-page academic article or 59 seconds of a 10-minute musical work in an online, password-protected course. It is essentially impossible to measure how often the guidelines have succeeded in helping instructors, since those who are helped ask no questions. Negative results do, however, generate questions, often ones that the guidelines could not answer even with a careful reading since the situations are complex. One example is below. 


\section{Instructor questions}

Quick question. I'm developing an online course at MSU and would like to know if I can scan in the cover of a book or movie and post the images online for the course. What are my options? - 8 Nov 2005

This is a real question that came to me from an instructor at MSU. It is typical both of the kind of question that teaching faculty have about the use of materials in online teaching. The instructor gave permission to quote the emails anonymously. I will use the pronoun "he" and the adjective "his" without any implication about the instructor's gender.

My e-mail response was brief:

Cover art is protected under copyright law, but a thumbnail image would be OK, if you are mainly using it a) as a reference to a site where the book/movie can be purchased/ viewed, and b) it is on Angel and limited to enrolled students only... If that's not quite the situation, let's talk on the phone. My direct line is below. - Seadle, 9 Nov 2005

"Angel" is the courseware management system from CyberLearning Labs that MSU uses for the majority of its online classes, including those that are purely distance education, those that mix classroom and online learning, and those that are purely classroom-based where the instructor wants to post lecture notes and other information.

What I did not include in my email response was any discussion of whether cover art was safer to use than other images. In strict legal terms, cover art has the same protection as any other copyright-protected work. In practice, however, cover art is created in order to help sell a particular book. The rights owner (probably the publisher) could find it perfectly acceptable to have the cover reproduced in a context that might help to sell additional copies of the book. The problem with that kind of explanation is that it involves a risk assessment that has to factor in the type of publisher, the context in which the cover would be used, and institutional angst over potential lawsuits. For example, an art book publisher might take exception to instructors using high-quality reproductions of paintings on book covers if the discussion said nothing about the content of the book and thus did nothing to help sales.

The instructor responded to my email with a burst of questions that showed both a respect for the law and a considerable uncertainty about how to interpret it.

Here are a few of the questions that I have had in the past.

May we use a scanned image from a book?

May we use images collected from the internet (regardless of copyrights)?

May we use clips from TV shows, movies, or soundbites?

May we provide a PDF article directly for download-or do we have to link it?

May we use any of these without permission from an author, publisher, producer?

*All of these will be used only once throughout the course and not altered in any way. Only registered students will have access through ANGEL. Media clips are all less that 3 minutes (most are less than 1 minute) and there are a few programs with more than one clip being used. PDF articles have been obtained from authors, MSU electronic sources, and other sources that we have paid dues to be able to access these files. - 11 November 2005

These questions had to be addressed in face-to-face conversations. Much of my work in advising instructors about copyright law comes down to issues of judgment. Leaving these judgments to individual instructors would expose an institution to a very broad range of interpretations, and might tend to err on the

Copyright in the networked world 
LHT

24,2

308 side of the needs of the instructor and his students rather than the rights holders and the university.

The instructor's questions are addressed below.

\section{Images and the TEACH Act}

This course involved the natural sciences. This was an advantage in terms of a fair use argument, because the images had clearly been created for scholarly purposes - a key factor in the second of the "Fair Use" tests in 17 USC 107.

All of the images were new enough to have copyright protection. That was a disadvantage. In copyright law, images are normally considered as separate and complete works, even when part of a larger work such as a book. This meant that the instructor's use of images automatically failed the third of the "Fair Use" tests in 17 USC 107 on amount and substantiality.

Use of a scanned image from a book would be an infringement. But if the use were part of the face-to-face equivalent portion of an online course, in which the instructor were using the image to illustrate a point he was making, rather than as something that was fundamentally background reading, the TEACH Act (part 2 of 17 USC 110) would provide a reasonable justification as long as other TEACH Act conditions were met.

The TEACH Act requires an institution to limit transmission of the copy "to the extent technologically feasible" to students enrolled in the course (17 USC 110). The law also requires the application of "technological measures that reasonably prevent - (aa) retention of the work in accessible form by recipients of the transmission from the transmitting body or institution for longer than the class session; and (bb) unauthorized further dissemination of the work in accessible form by such recipients to others; ..." (17 USC 110).

Some institutions have decided not to invoke the TEACH Act (at least officially) because of uncertainty about whether they can meet its conditions. My recommendations have generally treated the TEACH Act as applicable. Nonetheless we know that no software can really prevent the capture of anything that is visible on a computer screen.

\section{Internet-based images}

The use of internet-based images is not fundamentally different from those in books, except that an instructor can reasonably link to most online images. Most instructors have a strong preference for copying over linking because linked images can vanish suddenly in the middle of a semester, and because linking takes students out of the context of the course-based commentary. Linking is safer for the institution, however. This is a case where a thumbnail image might reasonably play a role in giving students an idea of the original image and act as a hyperlink if they want to see the full version. This kind of use is consistent with what the courts decided in Kelly vs Arriba Soft Corp2002 (US Court of Appeals).

\section{Multimedia}

The use of clips from TV shows, movies or sound bites is a question where the guidelines can generally provide an answer. Thirty seconds or 10 per cent (whichever is shorter) is not as restrictive as it may seem for a well-chosen example. In theory the 
TEACH Act allows greater use of multimedia within the bounds of the phrases "reasonable and limited" and "comparable to that which is typically displayed in the course of a live classroom session..." A unique problem with multimedia is the litigiousness of the rights owners. Copyright policing is almost entirely up to the rights owners, and the multimedia rights owners organizations (e.g. the Recording Industry Association of America or RIAA) are more active than print publishers in chasing down possible infringements. Since, universities tend to be risk adverse, sticking to limited and well-known guidelines makes sense.

\section{Other copies}

Using a PDF of an entire article is clearly not allowed under the TEACH Act. The act specifically excludes "textbooks, course packs, or other material in any media, copies or phonorecords of which are typically purchased or acquired by the students in higher education" from the exemptions allowed as part of "mediated instructional activities." (17 USC 110) The university licenses many electronic journals, but very few contracts with the publishers allow instructors to put copies into their courses. Instead they expect students to go to the publisher's own web site with all of its branding.

\section{Fair use and teaching}

The simple answer to the instructor's final question: "May we use any of these without permission from an author, publisher, producer?" is "no." Any use of copyright-protected materials without the rights holder's permission represents a potential infringement that can have expensive consequences. Willful infringement can cost up to $\$ 150,000$ per instance (17 USC 504, 2006). Many instructors would like to think that any educational use is fair, and the preamble to section 107 encourages this:

...use by reproduction in copies or phonorecords or by any other means specified by that section, for purposes such as criticism, comment, news reporting, teaching (including multiple copies for classroom use), scholarship, or research, is not an infringement of copyright. - 17 USC 107

But the next sentence in the preamble makes it clear that four factors must be considered as part of any fair use determination, one of the most important of which is "the effect of the use upon the potential market for or value of the copyrighted work." (17 USC 107).

A less simple answer to that final question is also possible. Institutions may authorize certain staff members to determine whether an orphaned work (whose rights owner cannot be located) may be used without permission. Such cases do come up but rarely with actively published journals such as were used for this course.

\section{Conclusion}

Each copyright use assessment has unique circumstances, but a discussion of the reasoning behind an actual case helps to build a community of good practice that strengthens similar assessments.

The point of this article has been to look at some of the more abstract issues that I have discussed in earlier columns in the context of what a real instructor is asking for a course that is being taught even as I write. Balancing fair use, the TEACH Act, case law, new discussions about orphaned copyrights, and an institution's willingness to take on a modest amount of risk requires an expertise that most instructors never
Copyright in the

309 
LHT

24,2

310

receive in their years of doctoral training, even though it increasingly affects how and what they do in the classroom and its online virtual equivalent.

No set of general guidelines suffices to give an individual instructor the information necessary to make reliable judgments. The most such tools can do at this point is to help instructors to ask more focused questions and to avoid the clearest and most blatant problems.

\title{
References
}

Seadle, M. (2005), Copyright and Online Learning Seminar, accessed March 2006.

17 USC 107 (2006), United States Code, Title 17, Chapter 1, section 107, available at: www.copyright.gov/title17/92chap1.html\#107, accessed March 2006.

17 USC 110 (2006), United States Code, Title 17, Chapter 1, section 110, available at: www.copyright.gov/title17/92chap1.html\#110, March 2006.

17 USC 504 (2006), United States Code, Title 17, Chapter 1, section 504, available at: www.copyright.gov/title17/92chap5.html\#504, March 2006.

US House of Representatives, Committee on the Judiciary, Subcommittee on Courts and Intellectual Property (1996), "Fair use guidelines for educational multimedia", available at: www.libraries.psu.edu/mtss/fairuse/dalziel.html

AAP (1976), "Agreement on guidelines for classroom copying in not-for-profit educational institutions with respect to books and periodicals", available at: www.publishers.org/ conference/pubinfo.cfm?PublicationID = 3, accessed March 2006, (American Association of Publishers).

US Copyright Office (1998), "Reproduction of copyrighted works by educators and librarians", Circular 21, US Copyright Office, Washington, DC, p. 8, available at: www.copyright.gov/ circs/circ21.pdf, accessed March 2006.

US Supreme Court (1985), "Harper \& Row, Publishers, Inc., et al. vs. Nation Enterprises et al." US Court of Appeals for the 9th Circuit (2002), "Kelly vs Arriba Soft Corp.".

US Congress (1998), Digital Millennium Copyright Act of 1998, available at: www.copyright.gov/ legislation/dmca.pdf, accessed March 2006.

\section{Further reading}

CONTU (1978), "Final report of the national commission on new technology uses of copyrighted works", available at: http://digital-law-online.info/CONTU/, accessed March 2006, (Commission on New Technological Use).

US House of Representatives (1996), Committee on the Judiciary, Subcommittee on Courts and Intellectual Property, available at: http://eric.ed.gov/ERICDocs/data/ericdocs2/ content_storage_01/0000000b/80/24/50/03.pdf, accessed March 2006.

\begin{abstract}
About the author
Michael Seadle is editor of Library Hi Tech. He is also Copyright Librarian and Assistant Director for Systems and Digital Services at Michigan State University. He is not a lawyer, and nothing in this column should be considered legal advice. Michael Seadle can be contacted at: Seadle@msu.edu
\end{abstract}

To purchase reprints of this article please e-mail: reprints@emeraldinsight.com Or visit our web site for further details: www.emeraldinsight.com/reprints 